influences. IV Notes on the physicochemical and immunological characteris(3) growth of mice. J. Exp. Med.. I30: 955 (1969).

21. Lee, C. J and Dubos, $\mathrm{R}$ : Lasting biological effects of early environmental influences influences. VII. Metabolism of adenosine Med.. 135: 220 (1972).

exposed to early environmental stress. J. Exp. Med.. 135 : $220(1972)$. Lee, C. J., and Dubos, R.: Lasting biological eflects of early environition and influences. VIII. Effects of neonatal infection, perinatal malnutrion and crowding

$$
\text { (1972). }
$$

23. Lefkowitz, R. J and Haber, E.: A fraction of the ventricular myocardium that has the specificity of the cardiac beta-adrenergic receptor. Proc. Nat. Acad. Sci. U.S.A. 68: 1773 (1971).

24. Lefkowitz. R. J., Haber, E., and Olubilization and purification by affinity beta-adrenergic receptor protein: Solubilization and purification b.

chromatography. Proc. Nat. Acad. Sci. U.S.A., 69: 2828 (1972).

25. Lefkowitz, R. J.. Sharp. G. W. G., and Haber, E.: Specific binding of $\beta$-adrenergic catecholamines to

Biol. Chem., 248: 342 (1973).

26. Miledi. R., Molinoff, P., and Potter, L. T.: Isolation of the chol protein of Torpedo electric tissue. Nature, 449: 554 (1971).

27. Molinoff, P. B., and Axelrod, J.: Biochemistry of catecholamine. Ann. Rev. Biochem. 40:465 (197!).

28. Moore, B. W : A soluble protein characteristics of the nervous system. Biochem. Biophys. Res. Commun., 19: 739 (1965).

9. Moore, B. W., and Perez, V. J.: In: F. C. Carlson: Physiological and Biochemical Aspects of Nervous Integrity, p. 343 (Prentice-Hall, Englewood Cliffs, N.J., 1968).

30. Moore. S., and Stein, W. H.: Chromatographic determination of amino acids by the use of automatic recording equipment. Methods Enzymol. 6: 819 (1963).

31. Munro, H. N.: Metabolic regulation in relation to cell development. Fed. Proc. 29: 1490 (1970).

32. Naeye, R L Blanc W and Paul, C. Effect of maternal nutrition on the human fetus. Pediatrics, 52: 494 (1973).

33. Schramm, M. Feinstin H. E. Nainephrine

Copyright (C) 1975 International Pediatric Research Foundation, Inc. binding to the catecholamine receptor and activation of the adenylate cyclase in erythrocyte membranes. Proc. Nat. Acad. Sci. U.S.A. 69: 523 (1972).

34. Spackman, D. H., Stein, W. H., and Moore, S.: Automatic recording apparatus for use in the chromatography of amino acids. Anal. Chem., 30:1190 (1958). for use in the chromates Stereospecificity and 35. Tell, G. P. E., and Cuatrecasas, P.: $\beta$-Adrenergic receptors. Commun., 57: 793 lack of

36. Vincendon G. Waksman, A.. Uyemura, K., Tardy, J., and Gombos, G. Ultracentrifugat behavior of beef brain S-100 protein fraction. Arch. Biochem Biophys., 120: 233 (1967).

37. Weber, K., and Osborn, M.: The reliability of molecular weight determination by dodecyl sulfate-polyacrylamide gel electrophoresis. J. Biol. Chem.. 244: 4406 (1969).

38. Winick $M$ and Rosso, P.: The effect of severe early malnutrition on cellular growth of human brain. Pediat. Res., 3: 181 (1969).

39. Winick, M. Rosso, P. and Brasel, J. A.: Malnutrition and cellular growth in the Winick, M., Rosso, P., and Brasel, J. A.: Malnutrition and cellular growth ing Brain 199 (Ciba Foundation Symposium, 1971)

0. Chates River.

41. Dietrich \& Gambrill, Inc., Frederick, Md.

42. Pharmacia Fine Chemicals, Inc., Piscataway, N. J.

43. Eastman Kodak Co., Rochester, N. Y

44. Schwarz BioResearch, Inc., Orangeburg, N. Y

45. Calbiochem, Los Angeles. Calif.

46. ICl America, Inc., Bridgeport, Conn.

47. Union Carbide Corp.. Chicago, III.

48. Fisher Scientific Co., Fair Lawn, N. J.

49. Buchler Instrument, Inc., Fort Lee, N. J.

50. Sigma Chemical Co., St. Louis, Mo.

50. Sigma Chemical Co., St. Louis,

51. Worthington Biochemical Corp., Freehold,

52. Brinkmann Instruments, Westbury, N. Y.

53. Requests for reprints should be addressed to: C.-J. Lee, Sc.D., Bureau of Biologics, Bldg. 29. National Institutes of

54. Accepted for publication April 10, 1975.

\title{
Inhibition of RNA Synthesis by Acetyl Salicylate and Actinomycin D during Early Development in the Mouse
}

\author{
ANIL B. MUKHERJEE, MARIA CHAN, RICHARD WAITE, MARTIN I. METZGER, AND SUMNER J. \\ YAFFEE ${ }^{\prime 29}$ \\ Department of Pediatrics, School of Medicine, State University of New York at Buffalo, and Children's Hospital, \\ Buffalo, New York, USA
}

\section{Extract}

Experiments were designed to ascertain and compare the effects of acetyl salicylate and actinomycin D on RNA synthesis in mouse ocytes in vitro and in vivo. After exposure to the drugs the effects on synthesis were measured by incorporation of $\left[{ }^{3} \mathrm{H}\right]$ uridine and autoradiography. The results indicate that acetyl salicylate inhibits RNA synthesis in the treated oocytes as does actinomycin $D$. The only difference in the effects of these two drugs is that salicylate inhibits RNA synthesis to a much lesser degree than does actinomycin $D$. Effects from a short exposure to salicylate may be reversible; the same effects with actinomycin $D$ cannot be reversed. In utero exposure of the female fetus may lead to partial or total sterility (depending on the dose and time of exposure) of that fetus and/or abnormal development of the progeny from those mice (F2).
These results suggest that RNA synthesis in early oogenesis is a vital part of later development of the oocytes in adult mouse ovary. Inhibition of RNA may be one of the causes of malformations and sterility.

\section{Speculation}

During early stages of development a species of RNA (known as masked messenger RNA) is synthesized by the oocyte nucleus and stored in the cytoplasm. After fertilization this RNA is utilized for the production of proteins necessary for the development of the embryo. If this RNA synthesis is inhibited by some agent (e.g., drugs) malformation or infertility could ensue in the female progeny. 
Information on the molecular mechanisms by which some drugs cause malformation in the developing fetus is virtually nonexistent. There is increasing evidence, however, that regulation of early animal development may be dependent on sequential synthesis of different messenger RNA molecules (mRNA). These mRNA molecules are stored as stable cytoplasmic ribonucleoprotein particles, which subsequent to fertilization are utilized for the production of specific proteins for a limited time during development (7). This species of nucleic acid is known as masked messenger RNA. To date its presence has been documented in amphibian and sea urchin eggs (4). One possible mechanism leading to induction of malformation is by spt cific inhibition of such transcription and/or translation of this $\mathrm{r}$ asked messenger RNA during development. It is already known $t$ at an inhibitor of RNA synthesis, such as actinomycin D, caus $s$ developmental defects in amphibian (4) as well as in mammali, I eggs $(2,23)$. It would seem reasonable to believe that a block i RNA synthesis for a short period of time during development $\mathrm{t}$ ther directly or indirectly may be responsible for at least some of $t$ e large number of anomalies induced by drugs in experimental an mals.

The present investigations were designed to ascertain and compare the effects of acetyl salicylate upon $\mathrm{RN} A$ synthesis in mouse oocytes with those of actinomycin $\mathrm{D}$, which is a known inhibitor of DNA-dependent RNA synthesis. Additionally, we administered each of these drugs at a specific time during pregnancy to ascertain the immediate effects on the first generation $(F 1)$ and to determine long term effects on the second generation progeny produced by the mating of $\mathrm{Fl}$ females and normal untreated males.

\section{MATERIALS AND METHODS}

\section{OOCYTE COLLECTION AND CULTURE}

Follicular oocytes were obtained from the ovaries of 8-10-weekold randomly bred ICR/Ha strain mice. The ovaries were dissected out and placed on a depression slide containing a mixture of one-half normal saline and one-half Whitten and Bigger's oocyte culture media (22). They were then teased with a 20-gauge needle and fine forceps to release the oocytes into the media. Subsequent to this procedure, the oocytes with well-defined germinal vesicles were collected into a micropipette and put into a plastic Petri dish containing full strength media under oil. All the oocytes needed for olie experiment were collected and put into culture as quickly as possible to avoid the difference in culture time. Twelve to 15 mice were killed each time to obtain approximately 600 oocytes. The cultures were than incubated at $37^{\circ}$ in $5 \%$ $\mathrm{CO}_{2}$ in air. Four types of experiments were performed.

In Vitro Treatment of Oocvtes with Actinomvcin D and Acety Salicylate. Bloom and Mukherjee (2) have shown that actinomycin $D$ at a concentration of $1 \times 10^{-1} \mu \mathrm{g} / \mathrm{ml}$ or higher prevented maturation of oocytes. However, at a concentration of $1 \times 10^{-2}$ and $1 \times 10^{-3} \mu \mathrm{g} / \mathrm{ml}$, oocytes reached metaphase II, indicating apparent maturity. We have used these three concentrations of actinomycin D $\left(1 \times 10^{-1}, 1 \times 10^{-2}\right.$, and $\left.1 \times 10^{-3} \mu \mathrm{g} / \mathrm{ml}\right)$. After exposure to actinomycin $\mathrm{D}$ for $30 \mathrm{~min}$, oocytes were transferred to media containing $\left[{ }^{3} \mathrm{H}\right]$ uridine $(5 \mu \mathrm{Ci} / \mathrm{ml} \mathrm{sp}$ act: $1,900 \mathrm{mCi} \mathrm{mM}$ (26) and left in this media for $4 \mathrm{hr}$. Similarly, oocytes were treated in acetyl salicylate concentrations ranging from $1 \times 10^{-1} \mu \mathrm{g} / \mathrm{ml}$ to $10 \mu \mathrm{g} / \mathrm{ml}$ for $30 \mathrm{~min}$, followed by exposure to $\left[{ }^{3} \mathrm{H}\right] \mathrm{uridine}(5$ $\mu \mathrm{Ci} / \mathrm{ml}$ ) for $4 \mathrm{hr}$. The control cultures received equal volumes of the solvent, normal saline. The oocytes were then washed thoroughly in saline, fixed on the slide with 1:3 glacial acetic acid and absolute methanol, and air dried. All slides were extracted with trichloroacetic acid $(5 \%)$ at $4^{\circ}$ for 30 min to eliminate the unincorporated isotopic pool. After this, they were coated with Kodak $\mathrm{NTB}_{2}$ nuclear track liquid emulsion and exposed in the dark at $4^{\circ}$ for 3 weeks before developing. They were stained in buffered Giemsa. All slides were coded and scored blindly by one person. Some slides were digested with RNAase and subsequent autoradiography revealed no radioactivity, indicating the incorporation of $\left[{ }^{3} \mathrm{H}\right]$ uridine solely in the RNA.

In Vivo Treatment of Oocvtes with Actinomvcin D and Acetvl Salicvlate. For this purpose actinomycin D and acetyl salicylate were injected $(1.5 \mathrm{ml} / 20 \mathrm{~g}$ body $\mathrm{wt})$ intraperitoneally $1 \mathrm{hr}$ before injection of $\left[{ }^{3} \mathrm{H}\right]$ uridine $(50 \mu \mathrm{Ci} / 20 \mathrm{~g}$ body wt $)$. The control group received the same volume of solvent plus $\left[{ }^{3} \mathrm{H}\right]$ uridine. For each treatment, six mice were used. The oocytes were isolated from the ovary and autoradiographs prepared as described above. They were coded and scored blindly by one individual for labeled and nonlabeled oocytes.

In Vitro Fertilization and Development of Treated Oocytes. From our previous experience in treatment of mouse oocytes with actinomycin D and acetyl salicylate and their subsequent development, and from the data presented by Bloom and Mukherjee (2), we arrived at a dosage of these drugs which consistently prevents RNA synthesis without apparent morphologic change in the maturation process of the oocyte. To find out whether or not these oocytes have full developmental potential, they were utilized for in vitro fertilization and subsequent development to the blastocyst stage. The concentration of the two drugs used in in vitro experiments were actinomycin D, $1 \times 10^{-3} \mu \mathrm{g} / \mathrm{ml}$, and acetyl salicylate, $10 \mu \mathrm{g} / \mathrm{ml}$. The oocytes were exposed to these drugs for 1 $\mathrm{hr}$ and then transferred to fresh drug-free media and allowed to grow to maturity for $10-12 \mathrm{hr}$. They were then transferred to the fresh culture media with capacitated sperm suspension for in vitro fertilization as described by Mukherjee (12). The number of oocytes undergoing cleavage was recorded as evidence for fertilization.

Inhibition of RNA Sunthesis in Fetal Ovary and Its Consequences. Since we obtained clear indication that acetyl salicylate does inhibit RNA synthesis in maturing oocytes, we wanted to see the consequences of this inhibition of RNA synthesis in the fetal ovary. In our previous studies we found that RNA synthesis in fetal ovaries takes place as early as 16-18 days of gestation with cytoplasmic storage in the oocyte (14). The control animals, which were at their 16 th-18th day after the appearance of vaginal plug, received an intraperitoneal injection of $1.5 \mathrm{ml}$ normal saline divided into three equal injections followed in $1 \mathrm{hr}$ by $50 \mu \mathrm{Ci}$ of $\left[{ }^{3} \mathrm{H}\right]-$ uridine/mouse. The experimental group received a total of $1.5 \mathrm{ml}$ $10 \mu \mathrm{g} / \mathrm{ml}$ acetyl salicylate/mouse in three equal injections on the 16 th day and again on the 17 th day when peak RNA synthesis occurs. At this time $50 \mu \mathrm{Ci} /$ mouse of $\left[{ }^{3} \mathrm{H}\right]$ uridine was also administered. Similarly, $1.5 \mathrm{ml}$ actinomycin $\mathrm{D}$ at a concentration of $1 \times$ $10^{-2} \mu \mathrm{g} / \mathrm{ml}$ was injected into each mouse in three equal doses before the injection of $\left[{ }^{3} \mathrm{H}\right]$ uridine as described for acetyl salicylate. When these progeny were born they were allowed to grow to maturity. At this time, the ovaries were taken out, oocytes were isolated, and autoradiographs were prepared. In another group of animals only the drugs were injected into the mother on the 16th18 th day of gestation but no isotope was administered. When these mothers delivered, the progeny were allowed to grow to maturity. At 6-8 weeks of age the female progeny were mated with males of proven fertility to see whether normal pregnancy resulted. These data were compared with that of the control progeny whose mothers received equal volumes of the drug solvents on the same days as the drug was introduced to the experimental group.

\section{RESULTS}

The normal process of maturation of oocytes in vitro has been published elsewhere (13). Approximately 9 of the oocytes reached second metaphase of meiosis at $16-17 \mathrm{hr}$ after initiation of the cultures. In the labeling experiments with $\left[{ }^{3} \mathrm{H}\right]$ uridine it has been observed that appreciable isotope incorporation took place between $26 \mathrm{hr}$. Therefore, in all experiments a 4-hr pulse was used. incorporation of $\left[{ }^{3} \mathrm{H}\right]$ uridine was indeed into the RNA of the oocytes. This was confirmed because $(l)$ the isotope was not 


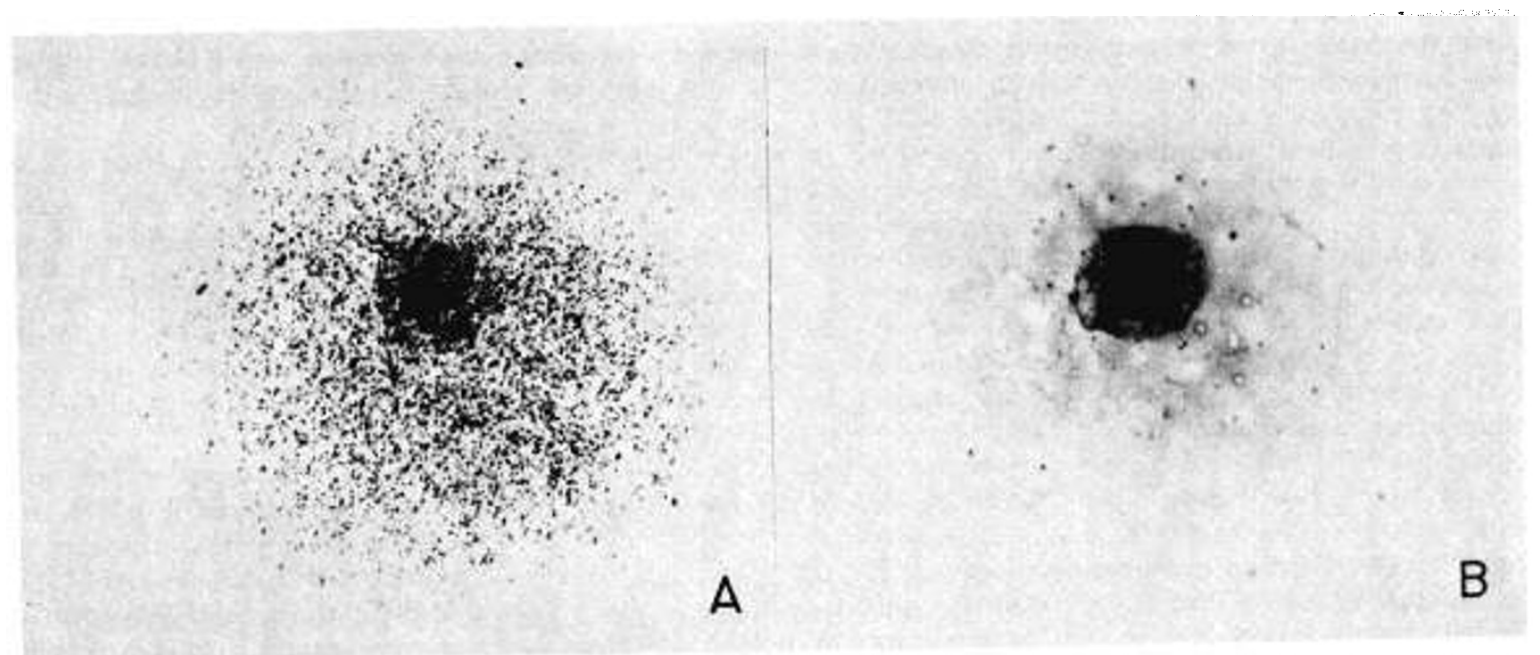

Fin synthesis in oocytes maturing in vitro. $A:\left|{ }^{3} \mathrm{H}\right|$ uridine incorporation in a mouse oucyte. The oucytes were extracted with cold iche

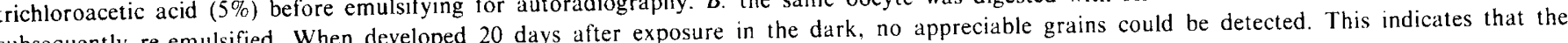
$\left[{ }^{3} \mathrm{H}\right]$ uridine label was incorporated solely into the RNA.

Table 1. In vitro effects of actinomycin $D$ and acetyl salicylate on $R N A$ synthesis in mouse oocytes

\begin{tabular}{|c|c|c|c|c|c|}
\hline Drug & Dose, $\mu \mathrm{g} / \mathrm{ml}$ & $\begin{array}{l}\text { No. oocytes } \\
\text { treated }\end{array}$ & $\begin{array}{c}\text { No. } \\
\text { labeled }\end{array}$ & $\begin{array}{c}\text { No. } \\
\text { unlabeled }\end{array}$ & labeled, \% \\
\hline \multirow[t]{3}{*}{ Actinomycin D } & $1 \times 10^{-1}$ & 276 & 4 & 272 & 1.4 \\
\hline & $1 \times 10^{-2}$ & 258 & 17 & 241 & 6.6 \\
\hline & $1 \times 10^{-3}$ & 250 & 28 & 222 & 11.2 \\
\hline Control & Culture media & 280 & 235 & 45 & 83.9 \\
\hline \multirow[t]{3}{*}{ Acetyl salicylate } & 10 & 269 & 6 & 263 & 2.2 \\
\hline & $1 \times 10^{-1}$ & 280 & 21 & 259 & 7.5 \\
\hline & $1 \times 10^{-3}$ & 256 & 44 & 212 & 17.1 \\
\hline Control & Culture media & 260 & 229 & 31 & 88.0 \\
\hline
\end{tabular}

Table 2. In vivo treatment of oocites with actinomycin $D$ and acetyl salicylate

\begin{tabular}{|c|c|c|c|c|c|}
\hline Drug & $\begin{array}{c}\text { Dose }(1.5 \mathrm{ml}) \\
\mu \mathrm{g} / \mathrm{ml}\end{array}$ & $\begin{array}{l}\text { No. mice } \\
\text { treated }\end{array}$ & $\begin{array}{l}\text { No. oocytes } \\
\text { studied }\end{array}$ & $\begin{array}{c}\text { No. labeled } \\
\text { oocytes/No. } \\
\text { unlabeled }\end{array}$ & $\begin{array}{c}\text { Labeled } \\
\text { oocytes, \% }\end{array}$ \\
\hline \multirow[t]{3}{*}{ Actinomycin D } & $1 \times 10^{1}$ & 10 & 320 & $9 / 320$ & 2.8 \\
\hline & $1 \times 10^{-2}$ & 10 & 300 & $31 / 269$ & 10.3 \\
\hline & $1 \times 10^{-4}$ & 10 & 332 & $68 / 264$ & 20.4 \\
\hline Control & N saline & 10 & 315 & $300 / 15$ & 90.5 \\
\hline \multirow[t]{3}{*}{ Acetyl salicylate } & 10 & 10 & 330 & $16 / 314$ & 4.8 \\
\hline & $1 \times 10^{-2}$ & 10 & 325 & $36 / 289$ & 11.0 \\
\hline & $1 \times 10^{-3}$ & 10 & 336 & $79 / 257$ & 23.5 \\
\hline Control & $N$ saline & 10 & 328 & $312 / 16$ & 95.1 \\
\hline
\end{tabular}

extractable with trichloroacetic acid and (2) treatment with RNAase removed all radioactivity from the oocyte (Fig. 1).

Table 1 compares the in vitro effects of actinomycin D and salicylate on RNA synthesis in the oocytes. After an hour of treatment with salicylate, oocytes were washed and put into fresh culture media. They resumed RNA synthesis, although to a lesser extent than normal. This treatment of actinomycin D-treated oocytes did not revive their RNA synthetic capability. However, both actinomycin D and acetyl salicylate inhibited RNA synthesis in the oocytes (Tables 1 and 2).

The most important biologic assay for the effects of inhibition of
RNA synthesis came from our observations on in vitro and in vivo fertilization. The results of in vitro fertilization using the treated oocytes and capacitated sperm are provided in Table 3 . It is clear from these data that actinomycin $D$, at a concentration which allows apparent progression of the oocytes to the second metaphase, does affect the process of fertilization, as well as normal cleavage and development of the embryo. Also, acetyl salicylate, like actinomycin $D$, prevented normal fertilization and developmental processes in the mouse.

The RNA synthesis in the fetal ovary during 16th-18th days of gestation was inhibited when actinomycin $\mathrm{D}$ and/or acetyl salicy- 
Table 3. In vitro fertilization and development of in vitro treated oocytes

\begin{tabular}{|c|c|c|c|c|c|c|c|c|}
\hline \multirow[b]{2}{*}{ Drug } & \multirow[b]{2}{*}{ Dose, $\mu \mathrm{g} / \mathrm{ml}$} & \multirow{2}{*}{$\begin{array}{c}\text { No. oocytes } \\
\text { treated }\end{array}$} & \multicolumn{2}{|c|}{$\begin{array}{l}\text { Oocytes } \\
\text { matured }\end{array}$} & \multirow{2}{*}{$\begin{array}{l}\text { No. used for } \\
\text { fertilization }\end{array}$} & \multicolumn{2}{|c|}{$\begin{array}{l}\text { Two-cell } \\
\text { embryos }\end{array}$} & \multirow{2}{*}{$\begin{array}{c}\text { No. } \\
\text { blastocysts }\end{array}$} \\
\hline & & & No. & $(\%)$ & & No. & $(\%)$ & \\
\hline Actinomycin D & $1 \times 10^{-3}$ & 916 & 380 & $(41.4)$ & 320 & 68 & $(21.2)$ & 0 \\
\hline Control & & 858 & 825 & $(96.1)$ & 750 & 445 & $(59.3)$ & 218 \\
\hline Acetyl salicylate & 10 & 1,120 & 578 & $(51.6)$ & 550 & 160 & $(29.0)$ & 4 \\
\hline Control & & 1,018 & 998 & $(98.0)$ & 964 & 494 & $(51.2)$ & 300 \\
\hline
\end{tabular}

Table 4. Effects of actinomycin $D$ and acetyl salicylate on $R N A$ synthesis in fetal ovarian oocytes in mice

\begin{tabular}{|c|c|c|c|c|c|c|}
\hline Drug & $\begin{array}{l}\text { Dose/mouse } \\
(20 \mathrm{~g}), \mu \mathrm{g} / \mathrm{ml}\end{array}$ & $\begin{array}{l}\text { No. pregnant } \\
\text { mice injected }\end{array}$ & $\begin{array}{l}\text { No. progeny } \\
\text { born }\end{array}$ & $\begin{array}{c}\text { No. ovarian } \\
\text { oocytes labeled/ } \\
\text { total no. oocytes } \\
\text { studied }\end{array}$ & $\begin{array}{c}\text { No. oocytes } \\
\text { unlabeled }\end{array}$ & $\begin{array}{c}\text { Oocytes } \\
\text { labeled, \% }\end{array}$ \\
\hline Actinomycin D & $\begin{array}{l}1 \times 10^{-2} \\
(1.5 \mathrm{ml})\end{array}$ & 10 & $86(50 q, 36 t)$ & $36 / 500$ & 464 & 7.2 \\
\hline Control (N saline) & $(1.5 \mathrm{mi})$ & 10 & $90\left(48 q, 42 \_\right)$ & $476 / 520$ & 44 & 91.7 \\
\hline Acetyl salicylate & 10 & 10 & $92(42$ q, 50 љ) & $53 / 426$ & 373 & 12.4 \\
\hline Control & $(1.5 \mathrm{ml})$ & 10 & $89(40$ q, 49 ह $)$ & $410 / 448$ & 38 & 91.5 \\
\hline
\end{tabular}

Table 5. Reproductive capacity of female progeny treated in utero and mated when mature

\begin{tabular}{|c|c|c|c|c|c|}
\hline Treatment & Group & $\begin{array}{l}\text { No. in utero- } \\
\text { treated mice mated } \\
\text { (vaginal plug) }\end{array}$ & $\begin{array}{l}\text { No. mice } \\
\text { pregnant } \\
\text { (18 days) }\end{array}$ & $\begin{array}{c}\text { No. normal } \\
\text { progeny }\end{array}$ & $\begin{array}{c}\text { No. abnormal } \\
\text { progeny }\end{array}$ \\
\hline \multicolumn{6}{|l|}{ Actinomycin $\mathrm{D}^{1}$} \\
\hline $1 \times 10 \quad 02 \mathrm{~g} / \mathrm{ml}$ & 1 & 20 & 6 & 12 & 14 \\
\hline $1 \times 10^{-2}$ & 2 & $\underline{25}$ & $\underline{4}$ & $\underline{0}$. & 12 \\
\hline Total & & $\overline{45}$ & $\overline{10}(22 \%)$ & $\overline{12}$ & $\overline{26}$ \\
\hline Salicylate $^{1}$ & $l$ & 25 & 10 & 14 & 16 \\
\hline $10 \mu \mathrm{g} / \mathrm{ml}$ & 2 & $\underline{25}$ & 11 & 17 & 19 \\
\hline Total & & $\overline{50}$ & $\overline{21}(42 \%)$ & 31 & $\overline{35}$ \\
\hline \multirow[t]{2}{*}{ Control, $\mathrm{N}$ saline } & $l$ & 26 & 24 & 216 & 0 \\
\hline & 2 & 25 & $\underline{23}$ & $\underline{183}$ & $1(?)$ \\
\hline Total & & $\overrightarrow{51}$ & $\overline{47}(92.1 \%)$ & $\overline{399}$ & $\overline{1(?)}$ \\
\hline
\end{tabular}

${ }^{1}$ Dose is the same as that used in the in vitro experiments.

late had been administered to the dam (Table 4). Subsequently, when these progeny were tested for fertility, they were found to have lower capacity to reproduce than the controls. Although some morphologically normal progeny were born to the dams who received the drug, they were nonetheless definitely affected by the drugs as judged by their reproductive capability. It is quite evident from Table 5 that in utero-treated females had less ability to reproduce and gave birth to more abnormal progeny when compared with the controls. Various abnormalities in the first generation included extreme reduction in size of the fetuses in the treated group compared with nontreated controls (Figs. 2 and 3 ). However, a majority of the female progeny that received the drugs in utero had extreme reabsorption of the embryos (Fig. 4) or they were completely sterile (depending on the dose of the drug).

\section{DISCUSSION}

The pattern of RNA synthesis in oocytes in general has been studied previously by Oakberg (16) and by Baker (1). Bloom and Mukherjee (2) have demonstrated that treatment of the oocytes with actinomycin D prevents their maturation. However, the effects of inhibition of RNA synthesis on the developmental potential of mouse oocytes, presented in this report, have not been shown previously. The demonstration in the present investigation that acetyl salicylate, like actinomycin D, inhibits RNA synthesis in oocytes during development is important from the standpoint of fetal malformations in other species, perhaps including man, because with a few exceptions every prenatally ingested medication crosses the placenta (11) and in the United States mothers take an average of 4-5 medications during pregnancy $(15,17)$.

The teratogenic effects of salicylate in the mouse $(9,19)$ and in the rabbit $(5,19)$ are well documented. However, a review of the literature on the effects of salicylate on early development in mammals shows that very few studies have been performed concerning the effects on the preimplantation stages of embryos (6). Young et al., in 1972 (25), have shown toxic effects of sodium salicylate on preimplantation mouse embryos in a preliminary study. In Young's study only morphologic criteria of survival of embryos were studied. The present investigations point to one of the mechanisms by which malformations and/or lethal effects of some drugs may be exerted during early development, e.g., by inhibition of RNA synthesis in the oocyte. Aspirin and other salicylates have been recognized as teratogens in rats since the first report by Warkany and Takaes (21). Recently, Janakidevi and 


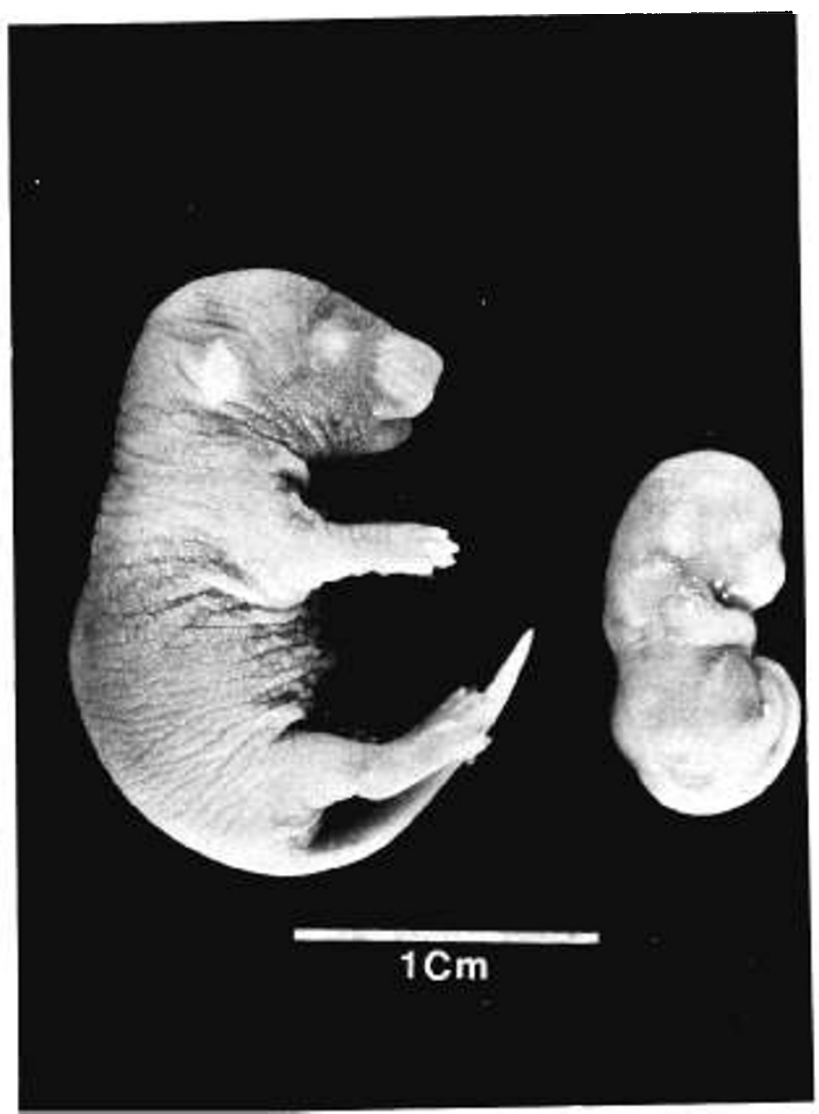

Fig. 2. Effect of salicylate $(10 \mathrm{~g} / \mathrm{ml}, 1.5 \mathrm{ml} / 24 \mathrm{hr})$ administered on the 16 th and 17 th day of gestation. Note the size of the fetuses on the $21 \mathrm{st}$ day of gestation when they were removed from the uterus. Left: control; right: treated.

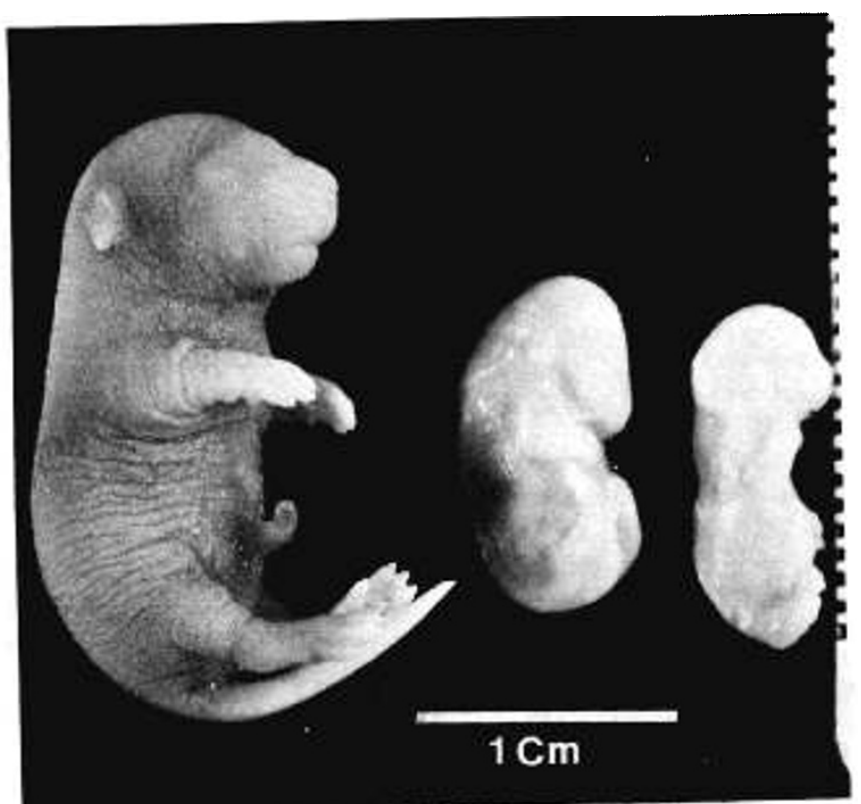

Fig. 3. Comparison of the progeny derived from mothers who received actinomycin $\mathrm{D}\left(1 \times 10^{-3} \mu \mathrm{g} / \mathrm{ml}\right)$, acetyl salicylate $(10 \mu \mathrm{g} / \mathrm{ml})$, and control. Left: control; middle: salicylate; right: actinomycin D.

Smith (8) have elucidated the molecular nature of salicylate action on living cells by pointing out that this drug indeed inhibits the nucleic acid polymerases in vitro. Our observations on the basis of autoradiographic evidence support the finding of those authors and further suggest that RNA synthesis in the maturing oocytes is an essential and integral part of the process of development and differentiation. Additionally, these results point to the possibility

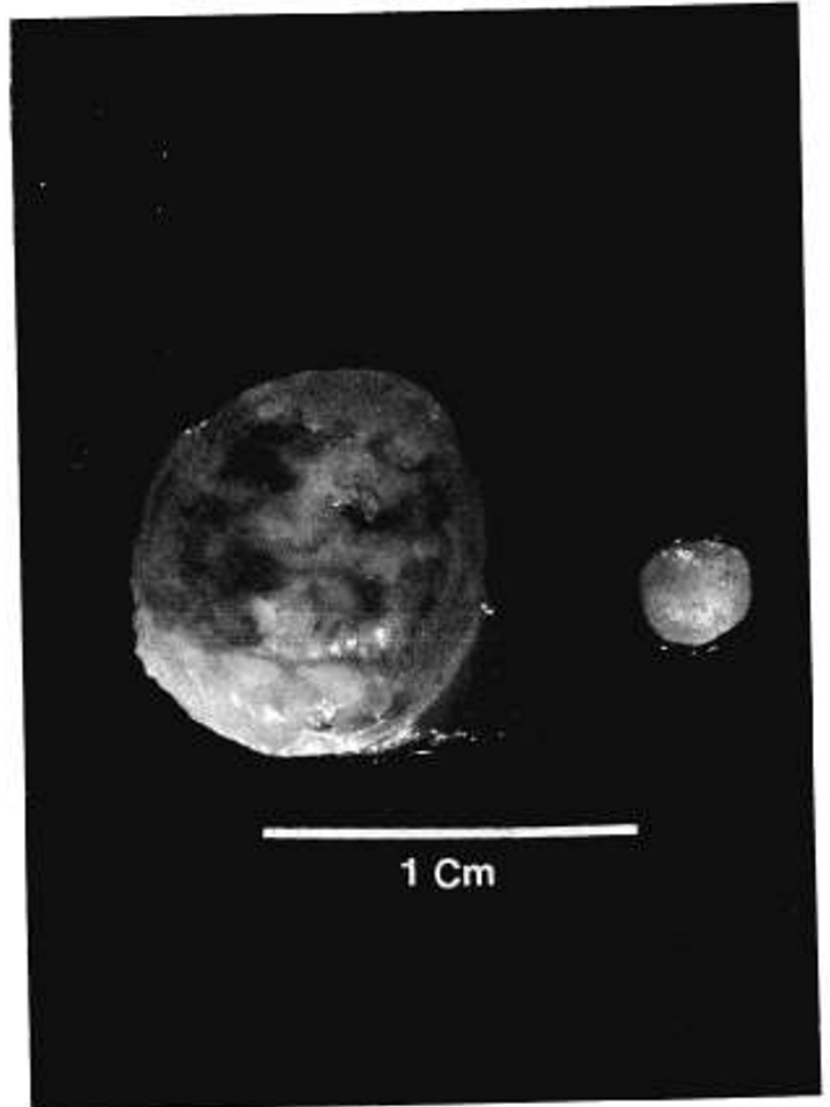

Fig. 4. A normal placenta compared to the reabsorbed fetus recovered from a mouse which was exposed to salicylate in utero during 15-18 days of gestation. 
that the inhibition of nucleic acid synthesis may be one of the reasons for the teratogenic effect and the reduction of fertility in the female mouse when exposed to acetyl salicylate in utero.

The reduction in fertility or complete sterility (depending on the dose) because of salicylate treatment in utero of the female fetus may be taken as indirect evidence of the inhibition of masked messenger RNA synthesis in the developing oocytes. It has been shown by Rudkin and Griech (18) and Borum (3) that the oocytes contained in the adult mouse ovary persist from fetal life and that the last round of DNA synthesis takes place in these oocytes during the 12 th- 15 th day of gestation. Our autoradiographic data obtained by injecting $\left[{ }^{3} \mathrm{H}\right]$ uridine into pregnant mice on the the 16 th 18 th day of gestation and recovering oocytes from adult progeny whose cytoplasm contained labeled RNA suggest that perhaps this is the time during which the fetal overy synthesizes masked messenger RNA, which is then stored in oocyte cytoplasm for future use after fertilization. This view has been further supported by the fact that the developmental potential of the oocytes of the progeny that received salicylate in utero during the 16 th-18th day of gestation is indeed reduced (Table 5). This effect of salicylate had been reported by Wright (24) who studied the toxicity of various analgesic and antipyrectic drugs for five generations in the mouse.

In conclusion, the present investigations suggest a possible mechanism for the adverse effects of salicylate in concentrations which fall within the therapeutic range in man, on the normal maturation and development of mouse oocytes. Extrapolation of these findings to humans must be considered with caution, in view of the difference in the process of oocyte maturation in human as compared with the mouse. However, the results of this study may be used to illustrate that drugs may affect progeny (at least in the mouse) adversely in one of three ways: $(I)$ by directly affecting the offspring in the early developmental processes such as organogenesis; (2) by antagonizing the RNA synthesis of their own oocytes during maturation in the ovary, and (3) by preventing RNA synthesis in the oocytes and/or normal maturation of the oocytes in their female offspring, thereby imposing sterility or the production of malformations in the subsequent generation.

\section{SUMMARY}

The effects of acetyl salicylate and actinomycin D on RNA synthesis in the mouse oocyte were compared by in vitro and in vivo experiments. After exposure to the drugs the effects on RNA synthesis were measured by incorporation of $\left[{ }^{3} \mathrm{H}\right]$ uridine and autoradiography. The results indicate that acetyl salicylate inhibits RNA synthesis in the treated oocytes in a manner similar to actinomycin D. The effects from a short exposure to salicylate may be reversible, whereas, the same effects with actinomycin D cannot be reversed. In utero exposure of the female fetus may lead to partial or total sterility (depending on the dose and time of exposure) of that fetus and/or abnormal development of subsequent progeny.

These results suggests that RNA synthesis in early oogenesis plays a vital role in the later development of the oocytes in adult mouse ovary. Inhibition of this early RNA synthesis may be one of the causes of subsequent malformations and sterility in future offspring.

Copyright $\odot 1975$ International Pediatric Research Foundation, Inc.

\section{REFERENCES AND NOTES}

1. Baker, T. A., Beaumont, H. M., and Franch, L. I.: The uptake of tritiated uridine and phenylalanine by the ovaries of rats and monkeys. J. Cell. Sci., 4: 655 (1962).

2. Bloom, A. M., and Mukherjee, B. B.: RNA synthesis in maturing mouse oocytes. Exp. Cell Res., 74: 577 (1972).

3. Borum, K.: Oogenesis in the mouse: A study of the origin of the mature ova. Exp. Cell Res., 45: 39 (1966).

4. Brachet, J., Denis, H., and de Vitry, F.: The effects of actinomycin D and puromycin on morphogenesis in amphibian eggs and acetabularia mediterranea. Dev. Biol., 9: 398 (1964).

5. Early, P. A., and Hayden, J.: Effect of acetyl salicylic acid on fetal rabbits. Lancet, i: 763 (1964).

6. Eriksson, M.: Salicylate induced fetal damage late in pregnancy. Acta Pediat. Scand. Suppl., 211: 5 (1971).

7. Gross, P. R.: RNA metabolism in embryonic development and differentiation. I. Fertilization and after. N. Engl. J. Med., 276: 1239 (1967).

8. Janakidevi, K., and Smith, M. J. H.: Inhibition of nucleic acid polymerases by salicylate in vitro. J. Pharm. Pharmacol., 21: 401 (1969).

9. Larsson, K. S., Bostrom. H., and Ericson, B.: Salicylate induced malformations in mouse embryos. Acta Pediat., 52: 36 (1963).

10. McColl, J. D., Golbus, M., and Robinson, S.: Effect of some therapeutic agents on the rabbit fetus. Toxicol. Appl. Pharmacol., 10: 244 (1967).

11. Moya, F., and Thorndike, V.: Passage of drugs across placenta. Amer. J. Obstet. Gynecol. 84: 1778 (1962).

12. Mukherjee, A. B.: Normal progeny from in vitro fertilization of mouse oocytes matured in culture and spermatozoa capacitated in vitro. Nature 237: 397 (1972).

13. Mukherjee, A. B.: In vitro embryogenesis: An experimental model for the understanding of reproductive physiology and development in mammals. Canad. J. Genet. Cytol., 16: 11 (1974).

14. Mukherjee, A. B.: RNA synthesis in developing oocytes (unpublished manuscript).

15. Nora, J. J., Nora, A. H., Sommerville, R. J., Hill, R. M., and McNamara, D. G Maternal exposure to potential teratogens. J. Amer. Med., Ass., 202: 1065 (1967).

16. Oakberg, E. F.: Relationship between stage of follicular development and RNA synthesis in the mouse oocytes. Mutat Res. 6: 155 (1968).

17. Peckham, C. H., and King, R. W.: A study of intercurrent conditions observed during pregnancy. Amer. J. Obstet. Gynecol. 87: 609 (1963).

18. Rudkin, A. T., and Griech, H. A.: On the persistence of oocyte nuclei from fetus to maturity in the laboratory mouse. J. Cell Biol., 12: 169 (1962)

19. Trasler, D. G.: Aspirin induced cleft lip and other malformations in mice. Lancet, i: $606(1965)$

20. Tyler, A.: Masked messenger RNA and cytoplasmic DNA in relation to protein synthesis and process of fertilization and determination in embryonic development. Dev. Biol. Suppl., I: 170 (1967).

21. Warkany, J., and Takaes, E.: Experimental production of cogenital malformations in rats oy salicylate poisoning. Amer. J. Pathol., 35: 315 (1959).

22. Whitten, W. K., and Biggers, J. D.: Complete development in vitro of the preimplantation stages of mouse in a simple chemically defined medium. $\mathbf{J}$. Reprod. Fertil., 17: 399 (1968)

23. Wilson, J. G.: Effects of acute and chronic treatment with actinomycin D on pregnancy and the fetus in the rat. Harper Hosp., Bull., 24: 109 (1966).

24. Wright, H. N.: Chronic toxicity studies of analgesic and antipyretic drugs and congeners. Toxicol. Appl. Pharmacol., 11: 280 (1967).

25. Young, L. M., Mukherjee, A. B., Cohen, M. M., and Yaffe, S. J.: Effects of sodium salicylate on preimplantation mouse embryos cultured in vitro. Recent Commun. Chem. Pathol. Pharm., 3: 579 (1972)

26. Schwarz BioResearch, Orangeburg, N. Y

27. We wish to thank Dr. Ronald Davidson for suggestions and critical review of the manuscript. We gratefully acknowledge the technical assistance of OK Kim and the editorial assistance of $\mathrm{M}$. Short.

28. This investigation was supported by grants from Department of Health, Education and Welfare Maternal and Child Health Service (Project 417), National Institutes of Health, (RR-05493, HD-05187, HD-06321, and HD-04287), and the Lalor Foundation.

29. Requests for reprints should be addressed to: S. J. Yaffe, M.D., Children's Hospital, Division of Pharmacology, 219 Bryant St., Buffalo, N. Y. 14222 (USA).

30. Accepted for publication April 10, 1975. 